\title{
FIRST REPORT OF SCLEROTIUM ROT OF FOLIAGE ORNAMENTAL PLANTS IN POLAND
}

\author{
Leszek Orlikowski*, Magdalena Ptaszek
}

Research Institute of Horticulture

Konstytucji 3 Maja Street 1/3, 96-100 Skierniewice, Poland

Received: March 1, 2013

Accepted: April 5, 2013

\begin{abstract}
Stem and leaf rot incited by Sclerotium rolfsii was found on Epipremnum aureum, Hedera helix, and Peperomia obtusifolia rooting cuttings. S. rolfsii was isolated from about $90 \%$ of the analysed plant materials. Isolate from E. aureum colonized all the parts of the 3 host plants as well as eustoma and lavender. Necrosis spread significantly faster on peperomia and the nonhost plants. The fungus produced dense, floccose, white mycelium with numerous, small, brown sclerotia. The optimum temperature for development was $30^{\circ} \mathrm{C}$.
\end{abstract}

Key words: occurrence, ornamental plants, pathogenicity, Sclerotium rolfsii, symptoms, temperature

\section{INTRODUCTION}

Epipremnum aureum, Hedera helix, and Peperomia obtusifolia are very popular foliage plants, which are grown under cover for the home market and for export. Within the last 10 years in Poland, Phytophthora stem base and leaf rot caused by Phytophthora palmivora was noticed on H. helix and P. obtusifolia whereas P. tropicalis on E. aureum (Orlikowski et al. 1996, 2006). In October 2012, disease symptoms were observed on the 3 above-mentioned plant species. The plants had been rooted in peat substratum in $1 \mathrm{dm}^{3}$ pots, on greenhouse benches. The first symptoms were noticed on E. aureum as pale-brown leaf spots. The diameters of the spots ranged from 2 to $5 \mathrm{~cm}$. These spots were covered with thick, white or whitecream fungal mycelium with tiny, about 1-2 mm diam, brown sclerotia. Fungus mycelium was also noticed on the surface of the peat with rooting cuttings as well as in pots with clean, wet substratum prepared for rooting of the next plants (Fig. 1). Two weeks later, the disease was noticed on about 5 day-old rooting cuttings of $H$. helix and P. obtusifolia. Brown or dark brown discoloration was observed on the base of stems and necrosis spread upwards on leaf petioles and blades. Among cuttings white mycelium spreading on the substratum surface was often seen. The disease spread from the affected to the healthy leaves of the next connected cuttings. The first purpose of this study was to detect a causal agent of the disease, and to evaluate its pathogenicity toward the host and nonhost plants, whereas the second was to estimate the influence of the temperature on pathogen growth and its harmfulness to P. obtusifolia leaf blades.

\section{MATERIALS AND METHODS}

\section{Greenhouse survey}

Commercial E. aureum, $H$. helix, and $P$. obtusifolia rooted cuttings and older plants growing on greenhouse benches and beds on an area of about $10000 \mathrm{~m}^{2}$, were surveyed for the presence of stem base and leaf rot symptoms. Disease symptoms were only noticed on about $5-10 \%$ of the rooted cuttings, mainly E. aureum. Affected plant species were collected separately in plastic bags together with substratum and transferred into the laboratory. After washing under the tap as well as with distilled water, the stem parts and leaves of the cuttings were separated. For each plant species, 20 affected stem parts and leaf blades were taken for mycological analysis.

\section{Detection and identification of fungi from affected plants}

Plant parts with necrosis symptoms were dabbed dry between 2 layers of blotting paper and sterilised over a burner flame. About $3 \mathrm{~mm}$ long, or diameter parts of them were transferred on PDA (Potato Dextrose Agar) medium into $90 \mathrm{~mm}$ Petri dishes and incubated 2-3 days at $25^{\circ} \mathrm{C}$ in the dark. Representative fungal colonies grown around the affected parts were transferred onto PDA slants and after a 7-day-incubation they were cleaned and transferred on PDA into Petri dishes. These cultures were identified to species on the base of morphological and cultural characteristics (Mordue 1974). To confirm morphological identification the internal transcribed spacer (ITS) rDNA region was amplified using the primers ITS1 and ITS4 (White et al. 1990) and sequenced. Obtained sequences were compared with those present in NCBI database. 


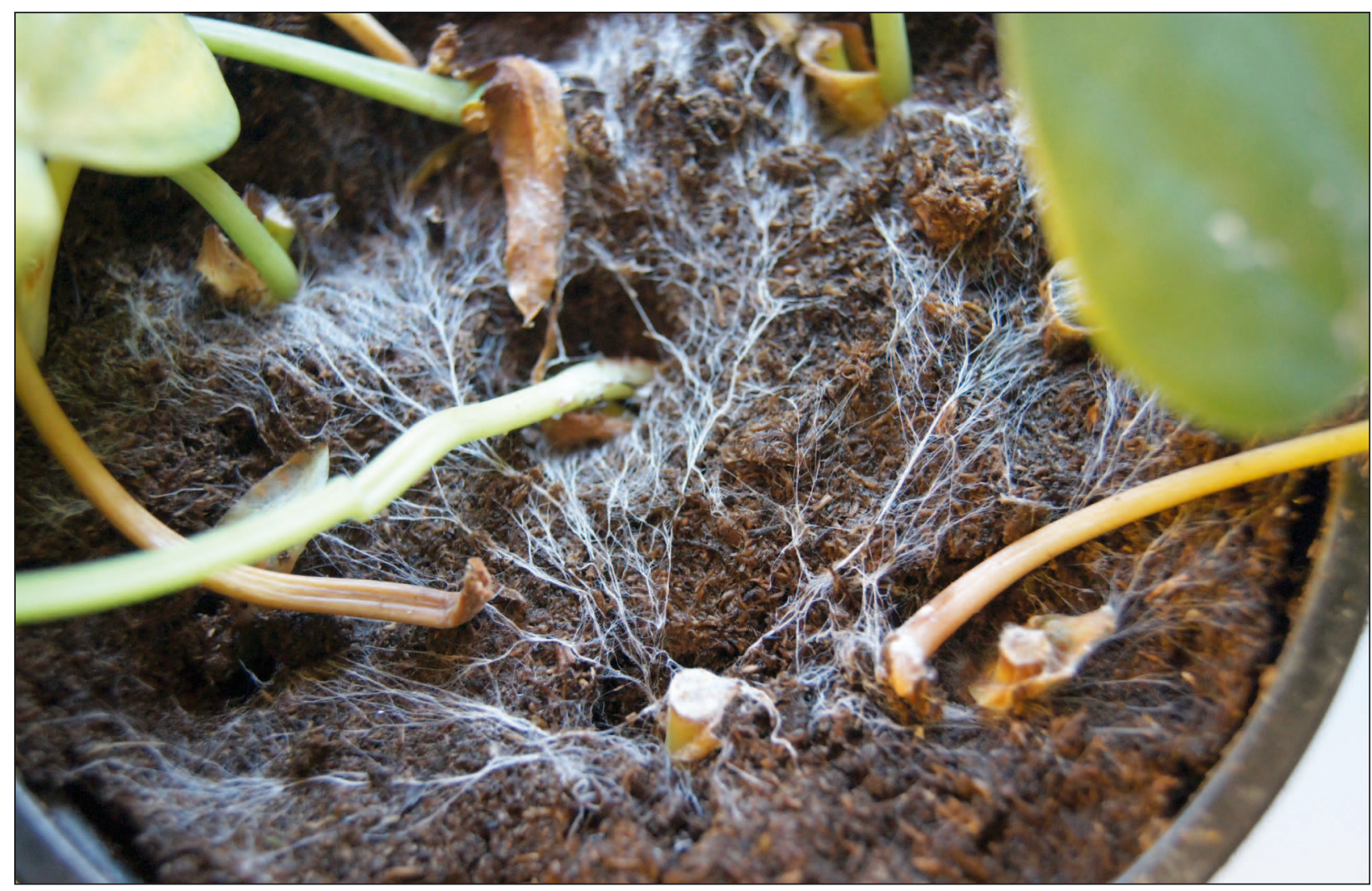

Fig. 1. Mycelium of S. rolfsii on the surface of peat and diseased parts of E. aureum

\section{Growth of S. rolfsii in relation to temperature}

For temperature growth relationship, PDA and malt extract agar (MEA) plates (90 $\mathrm{mm}$ diam) were inoculated with $5 \mathrm{~mm}$ diameter mycelial discs, taken from the edge of the 7-day-old culture. Plates were incubated for 24 hours at $20^{\circ} \mathrm{C}$ to stimulate the oneset of growth. Then four replicate plates were transferred to temperatures from 5 to $35^{\circ} \mathrm{C}$, at $5^{\circ} \mathrm{C}$ interval. Growth rate was recorded after 2-14 days, along two lines intersetting the centre of the inoculum at right angles (Hall 1993).

\section{Pathogenicity of S. rolfsii}

The procedure described by Orlikowski and Szkuta (2001) was used to evaluate the pathogenicity of the fungus toward E. aureum, H. helix, Lavandula angustifolia, Lisianthus grandiflorum, and P. obtusifolia. Plant parts were washed under tap water, dabbed dry and transferred to photographic trays containing moist sterile blotting paper covered with plastic net. Five-millimeter-diameter mycelial discs cut from the edge of 7-day-old PDA cultures were placed on one cut end of the stem parts (about $50 \mathrm{~mm}$ long), leaf petioles, roots, and in the centre of wounded leaf blades. As a control, clean PDA discs were used. Trays were covered with folia and incubated at $22-24^{\circ} \mathrm{C}$. After a 3 and 5-day-incubation, the length and diameter of the necrosis was measured.

\section{Pathogenicity of $S$. rolfsii in relation to temperature}

Leaf blades of peperomia inoculated with S. rolfsii and located in trays were incubated at the same temperature as mentioned above (from $5-35^{\circ} \mathrm{C}$ ). The diameter of the necrosis was measured after 3 and 5 days.

\section{Statistical analyses}

The experimental design was completely randomized with 4 replications and 10 plant organs in each replication. In the case of the temperature test, 4 Petri dishes (4 replications) were used. Trials were repeated twice, at 2-week-intervals. Duncan's multiple range test was used for means separation.

\section{RESULTS AND DISCUSSION}

Identification of fungi obtained from affected plant parts

S. rolfsii was isolated from about $90 \%$ of the plant parts showing discoloration of stem bases and necrosis of leaf blades. Additionally, Botrytis cinerea, Fusarium avenaceum and Mucor spp. were rarely or only sporadically isolated from the affected plant tissues.

\section{Characteristic of $S$. rolfsii}

On PDA and MEA media, the fungus produced dense, floccose, white mycelium septate with clamp connections at the hyphal septa. Numerous sclerotia which were usually spherical and white at first then later pale-brown and brown were observed on the surface of cultures and especially in the middle. These sclerotia had diameters which ranged from 0.9 to $1.8 \mathrm{~mm}$. The fungus developed at temperatures from $5^{\circ} \mathrm{C}(0.01 \mathrm{~mm} / 24 \mathrm{~h})$ to $30^{\circ} \mathrm{C}$, with the optimum at $30^{\circ} \mathrm{C}$ (MEA 14.9; PDA $16.8 \mathrm{~mm} / 24 \mathrm{~h}$ ). The pathogen was unable to grow at $35^{\circ} \mathrm{C}$ (Fig. 2).

\section{Pathogenicity tests}

S. rolfsii colonised all the tested parts of the plant species (Table 1, Fig. 3). On host plants (E. aureum, H. helix, 


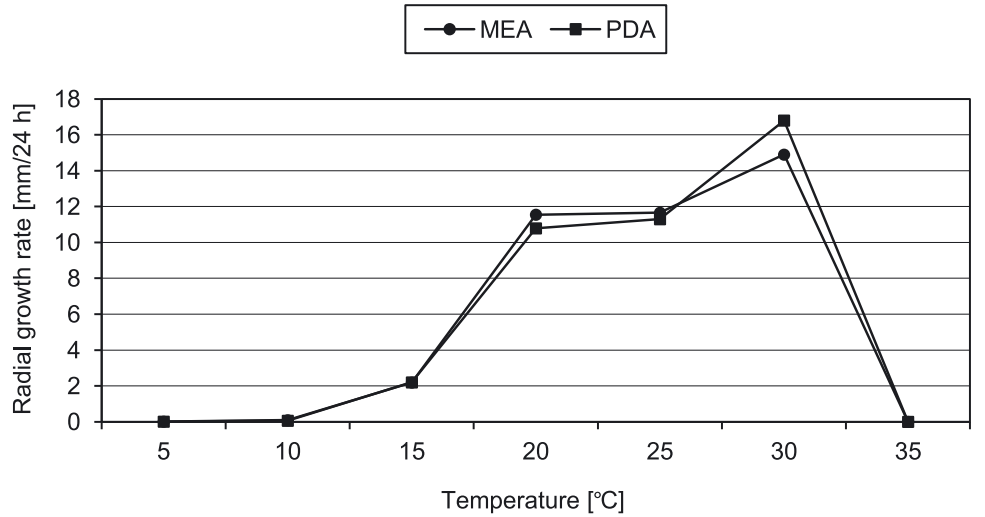

Fig. 2. Influence of temperature on the growth of S. rolfsii on Potato Dextrose Agar (PDA) and malt extract agar (MEA)

Table 1. Relationship between plant species, their parts, incubation time and colonization of tissues by S. rolfsii 3 (A) and 6 (B) days after inoculation

\begin{tabular}{|c|c|c|c|c|c|c|}
\hline \multirow{3}{*}{ Plant species } & \multicolumn{6}{|c|}{ Length of necrosis $[\mathrm{mm}]$ on plant organs } \\
\hline & \multicolumn{2}{|c|}{ stems } & \multicolumn{2}{|c|}{ leaf petioles } & \multicolumn{2}{|c|}{ leaf blades } \\
\hline & A & B & A & B & A & B \\
\hline Epipremnum aureum & $7.4 \mathrm{a}$ & $16.1 \mathrm{a}$ & $7.6 \mathrm{a}$ & $21.5 \mathrm{a}$ & $6.7 \mathrm{a}$ & $12.1 \mathrm{a}$ \\
\hline Lisianthus grandiflorum & $12.9 \mathrm{c}$ & $33.9 \mathrm{~cd}$ & $9.3 \mathrm{a}$ & $30.5 \mathrm{c}$ & $12.4 \mathrm{~b}$ & $27.2 \mathrm{c}$ \\
\hline Hedera helix & $7.1 \mathrm{a}$ & $24.6 \mathrm{~b}$ & $9.5 \mathrm{a}$ & $21.3 \mathrm{a}$ & $6.3 \mathrm{a}$ & $17.0 \mathrm{~b}$ \\
\hline Lavandula angustifoila & $14.0 \mathrm{c}$ & $36.0 \mathrm{~d}$ & $10.5 \mathrm{~b}$ & $26.1 \mathrm{~b}$ & - & - \\
\hline Peperomia obtusifolia & $9.9 \mathrm{~b}$ & $31.3 \mathrm{c}$ & $12.5 \mathrm{~b}$ & $30.2 \mathrm{c}$ & $21.4 \mathrm{c}$ & $39.6 \mathrm{~d}$ \\
\hline
\end{tabular}

Means in columns, followed by the same letter, do not differ significantly at the $5 \%$ level according to Duncan's multiple range test

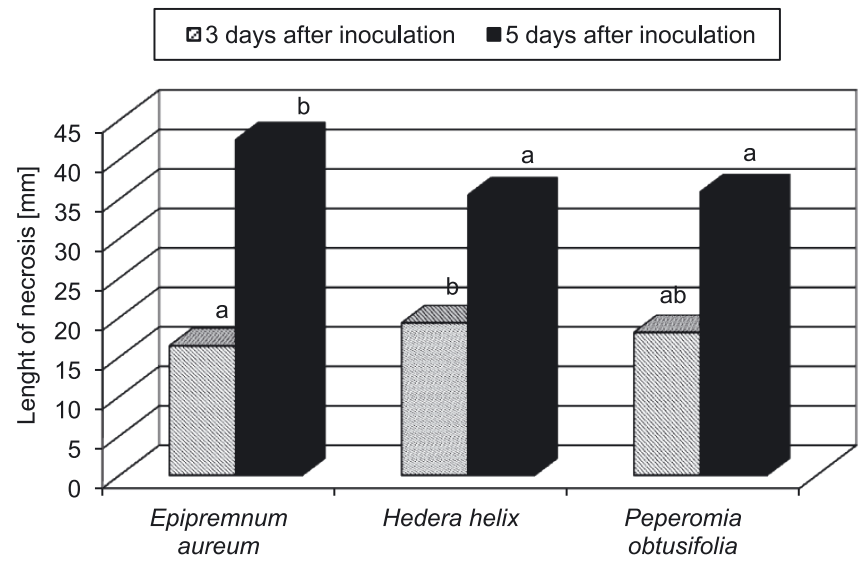

Means in columns, followed by the same letter, do not differ significantly at the $5 \%$ level according to Duncan's multiple range test

Fig. 3. Relationship between plant species, incubation time, and colonisation of roots by S. rolfsii

P. obtusifolia), significant differences in the colonisation of tissues were noticed. Within 3 and 6-day-incubation, peperomia parts were colonised faster than the other 2 species. The obtained results indicated that eustoma and lavender stem parts were colonised significantly faster than host plants (Table 1). Analysis of root colonisation indicated that the slowest necrosis development was on E. aureum roots within the first 3 days but later necrosis spread significantly faster than on H. helix and P. obtusifolia (Fig. 3).

On leaves of P. obtusifolia incubated at temperatures from 5 to $35^{\circ} \mathrm{C}$, necrosis development was observed at the range from 15 to $35^{\circ} \mathrm{C}$ with the optimum at $30^{\circ} \mathrm{C}$. At such temperatures necrosis spread about $10 \mathrm{~mm} / 24 \mathrm{~h}$ (Fig. 4).

S. rolfsii is not a new pathogen of ornamental plants. Aliteri and Knauss (1972) detected it in Florida, in the USA, from P. obtusifolia with stem and leaf rot symptoms 


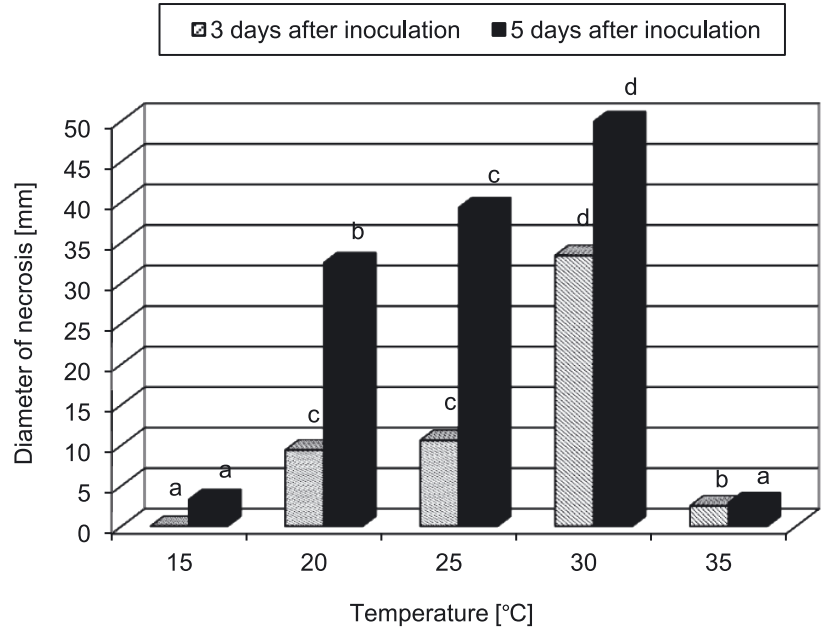

Means in columns, followed by the same letter, do not differ significantly at the $5 \%$ according to Duncan's multiple range test

Fig. 4. Colonisation of P. obtusifolia leaf blades by S. rolfsii in relation to temperature; diameter of necrosis 3 and 5 days after inoculation was lost

where greenhouse conditions were indicated as favourable for the fungus development. Chase (1987) described the species on 22 foliage ornamentals, including E. aureum, H. helix and P. obtusifolia. Daughtery et al. (1995) described the pathogen on 11 flowering pot species growing in the USA, as southern blight disease. The authors mentioned S. rolfsii as the pathogen of many agronomic, vegetable and ornamental crops. In the opinion of Chase (1987), the species attacks all parts of the plants, but especially the stems and leaves. Our observation confirmed this finding. The pathogen was also noticed in Italy on $H$. helix as the causal agent of southern blight (Pane et al. 2007). The symptoms on plants and characteristics of the species were similar to those noted in our study. S. rolfsii is also a very dangerous pathogen of orchids as described for the first time by Bag (2004) in the USA, on Cymbidium and its hybrids, and later on Phalaenopsis and Cymbidium in Korea (Han et al. 2011, 2012). Our studies also confirmed the data of Pane et al. (2007) and Han et al. (2012). They indicated $S$. rolfsii as the pathogen mainly in tropical and subtropical areas or plants growing in greenhouses where $30^{\circ} \mathrm{C}$ was optimum for its development. Pathogenicity tests on L. grandiflorum and L. angustifolia indicated that host range for S. rolfsii in Poland is also wider, especially for plants grown under cover. Colonisation of plant roots by the pathogen increased the possibility of surveying the pathogen in the form of sclerotia, in horticultural substrata.

\section{CONCLUSIONS}

1. S. rolfsii was detected from E. aureum, H. helix, and P. obstusifolia, as the casual agent of stem base and leaf rot.

2. The pathogen mycelium was observed on plants, pots, and substratum surfaces with formation of small brown sclerotia.

3. The development of the fungus was observed at $5^{\circ} \mathrm{C}$ to $30^{\circ} \mathrm{C}$, and colonisation of leaves was noticed in the temperature range from $15^{\circ} \mathrm{C}$ to $30^{\circ} \mathrm{C}$ with the optimum at $30^{\circ} \mathrm{C}$.

4. In laboratory trials, S. rolfsii colonised all the parts of the host plants.

\section{REFERENCES}

Alitieri S.A., Knauss J.F. 1972. Stem and leaf rot of peperomia incited by Sclerotium rolfsii. Florida State Hortic. Soc.: 352-357.

Bag T.K. 2004. Occurrence of orchid wilt (Sclerotium rolfsii Sacc.) in Cymbidium and its hybrids. Sci. Cult. 70: 287-288.

Chase A.R. 1987. Compendium of Ornamental Foliage Plant Diseases. APS Press, St. Paul. MN, USA, 92 pp.

Daughtery M.L., Wick R.L., Peterson J.L. 1995. Compendium of Flowering Potted Plant Diseases. APS Press, St Paul, MN, USA, $90 \mathrm{pp}$.

Hall G. 1993. An integrated approach to the analysis of variation in Phytophthora nicotianae and a redescription of the species. Mycol. Res. 97 (5): 559-574.

Han K.S., Lee S.C., Han Y.K., Kim S., Park J.H. 2011. Sclerotium blight of Phalaenopsis orchids caused by Sclerotium rolfsii in Korea. Res. Plant Dis. 17 (3): 402-404.

Han K.S., Lee S.C., Lee J.S., Soh J.W., Kim S. 2012. First report of Sclerotium rot on Cymbidium orchids caused by Sclerotium rolfsii in Korea. Mycobiology 40 (4): 263-264.

Mordue J.E. 1974. Corticium rolfsii. CMI descriptions of pathogenic fungi and bacteria. No. 410. Kew, Surrey: Commonwealth Mycol. Institute.

Orlikowski L.B., Sroka S., Szkuta G. 1996. Phytophthora stem and leaf blight of Hedera helix L. and Fatshedera lizei Guill. Phytopathol. Pol. 12: 87-94.

Orlikowski L.B., Szkuta G. 2001. Dieback of Pieris japonica caused by Phytophthora citrophthora. Acta Mycol. 36 (2): 251-256.

Orlikowski L.B., Trzewik A., Wiejacha K., Szkuta G. 2006. Phytophthora tropicalis, a new pathogen of ornamental plants in Poland. J. Plant Prot. Res. 46 (1): 103-109.

Pane A., Raudino F., Adornetto S., Projetto Russo G., Cacciola S.O. 2007. Blight of English ivy (Hedera helix) caused by Sclerotium rolfsii in Sicily. Plant Dis. 91 (5), p. 635.

White T.J., Bruns T., Lee S., Taylor J. 1990. Amplification and direct sequencing of fungal ribosomal RNA genes for phylogenetics. In: "PCR Protocols: a Guide to Methods and Applications" (M.A. Innis, D.H. Gelfand, J.J. Sninsky, T.J. White, eds.). Academic Press, San Diego: 315-322. 